\title{
Low level exposure to cadmium increases the risk of chronic kidney disease: analysis of the NHANES 1999-2006
}

\author{
Pietro Manuel Ferraro, Stefano Costanzi, Alessandro Naticchia, Antonio Sturniolo and Giovanni Gambaro*
}

\begin{abstract}
Background: Environmental factors have been associated with the outbreak of chronic kidney disease (CKD). We evaluated the association of Cadmium (Cd) exposure with the risk of CKD in U.S. adults who participated in the 19992006 National Health and Nutrition Examination Surveys (NHANES).

Methods: 5426 subjects $\geq 20$ years were stratified for values of urinary and blood $\mathrm{Cd}$ and a multivariate logistic regression was performed to test the association between blood and urinary Cd, CKD and albuminuria (ALB) after adjustment for age, gender, race/ethnicity, body mass index and smoking habits.
\end{abstract}

Results: Subjects with urinary $\mathrm{Cd}>1 \mathrm{mcg} / \mathrm{g}$ and subjects with blood $\mathrm{Cd}>1 \mathrm{mcg} / \mathrm{L}$ showed a higher association with ALB (OR 1.63, 95\% Cl 1.23, 2.16; $P=0.001)$. Subjects with blood $\mathrm{Cd}>1 \mathrm{mcg} / \mathrm{L}$ showed a higher association with both CKD (OR 1.48, 95\% Cl 1.01, 2.17; $P=0.046)$ and ALB (OR 1.41,95\% Cl 1.10, 1.82; $P=0.007)$. An interaction effect on ALB was found for high levels of urinary and blood $\mathrm{Cd}(P=0.014)$.

Conclusions: Moderately high levels of urinary and blood $\mathrm{Cd}$ are associated with a higher proportion of CKD and ALB in the United States population.

\section{Background}

Chronic exposure to Cadmium (Cd), an industrial and environmental pollutant, can cause both renal proximal tubular damage and decline in glomerular filtration rate (GFR) in humans; this has been confirmed in experimental models $[1,2]$. After pulmonary and/or gastrointestinal absorption, $\mathrm{Cd}$ binds to serum albumin and accumulates in the liver, where it is complexed to a metal-binding protein with a high affinity for $\mathrm{Cd}$, metallothionein-1 [3]. The Cd-metallothionein-1 complex reaches the kidney where it is filtered and accumulates in the proximal tubule, whose cells possess transporters for free and bound forms of Cd [4] and interferes with the tubular function.

Cadmium nephropathy is characterized by low molecular weight (LMW) proteinuria due to diminished intrarenal uptake and catabolism of filtered proteins. In

\footnotetext{
* Correspondence: giovanni.gambaro@rm.unicatt.it

1 Division of Nephrology and Dialysis, Columbus-Gemelli University Hospital, Renal Program, Catholic University, Rome, Italy

Full list of author information is available at the end of the article
}

Cadmium nephropathy, proximal tubular dysfunction persists until renal failure supervenes.

Although Cadmium nephropathy has been observed in workers exposed to high levels of $\mathrm{Cd}$, recent data suggest that relatively low levels of exposure in people living in polluted industrial areas increase the risk of tubular dysfunction [1]. Furthermore, analysis of the National Health and Nutrition Examination Survey (NHANES) databases have disclosed even in the general population the association of $\mathrm{Cd}$ exposure with some clinical conditions [5-7]. In particular, the very recent paper by Navas-Acien et al [8] has disclosed that marginally high levels of blood $\mathrm{Cd}$ are significantly associated with kidney dysfunction. However, blood Cd is considered to be a marker of the acute, short term exposition, rather than the chronic one which is much more relevant to Cadmium nephropathy [9]. Since the urinary excretion of $\mathrm{Cd}$ is assumed to mirror chronic exposition to $\mathrm{Cd}$, and Navas-Acien did not investigate this topic, we have specifically addressed 
whether an association exists between urinary $\mathrm{Cd}$ and renal dysfunction.

We analyzed the association between blood and urinary $\mathrm{Cd}$ levels and kidney abnormalities (chronic kidney disease [CKD] and albuminuria [ALB]) among U.S. adults who participated in the 1999-2006 NHANES surveys to support the idea that $\mathrm{Cd}$ exposition of the general population contributes to the epidemics of CKD in this population.

\section{Methods}

The NHANES is a cross-sectional nationally representative survey of the noninstitutionalized U.S. civilian population [10], and is regularly conducted in the U.S. by the National Center for Health statistics. It consists of standardized questionnaires administered in the home by trained interviewers followed by a detailed physical examination at a Mobile Examination Center. Data from the 1999-2000, 2001-2002, 2003-2004 and 2005-2006 NHANES surveys were available from the website http:// www.cdc.gov/nchs/nhanes.htm[10]. We limited our analysis to subjects $\geq 20$ years of age. Data relevant to the analysis included age, gender, race/ethnicity, body mass index (BMI), self-reported information about smoking habits.

A blood specimen was obtained from participants for blood $\mathrm{Cd}$ and creatinine. An untimed urine sample was obtained from a random subsample of participants for urinary $\mathrm{Cd}$, albumin and creatinine.

Exclusions for the current study included subjects without the measurements necessary for our analysis, and pregnant or menstruating women at the time of examination.

Cadmium concentrations were determined at the Environmental Health Sciences Laboratory of the CDC National Center for Environmental Health (NCEH) after confirmation of no background contamination and using extensive quality control procedures. For blood Cd measurements, a PerkinElmer Model SIMAA 6000 simultaneous multi-element atomic absorption spectrometer with Zeeman background correction was used. Urinary $\mathrm{Cd}$ concentrations were determined using inductively coupled plasma mass spectrometry.

The limit of detection for urinary $\mathrm{Cd}$ was $0.04 \mathrm{mcg} / \mathrm{L}$; of the study participants, $1.2 \%$ had urinary Cd levels below this limit.

The limit of detection for blood Cd was $0.30 \mathrm{mcg} / \mathrm{L}$ in NHANES 1999-2002 and 0.20 mcg/L in NHANES 20032006: $17.0 \%$ and $5.3 \%$ of the study participants had blood $\mathrm{Cd}$ levels below the limits of detection in NHANES 19992002 and NHANES 2003-2006, respectively.

In our analysis urinary $\mathrm{Cd}$ levels have been expressed as a urinary $\mathrm{Cd}$-to-creatinine ratio ( $\mathrm{mcg} / \mathrm{g}$ creatinine).
Serum and urinary creatinine concentrations were determined using the Jaffe kinetic alkaline picrate method. Estimated GFR (eGFR) was calculated from standardized serum creatinine using the CKD-EPI study equation [11].

Since proper use of GFR estimating equations requires a known calibration of the serum creatinine assays [12], unstandardized serum creatinine from the 1999-2000 survey was corrected applying the following formula, available from the NHANES website [10]:

corrected creatinine $=(1.013 *$ NHANES creatinine $)+0.147$

Uncalibrated serum creatinine from the 2005-2006 survey has been corrected using the formula [10]:

corrected creatinine $=-0.016+(0.978 *$ NHANES creatinine $)$

No creatinine calibration was needed for the 2001-02 and 2003-04 surveys values.

Urinary albumin concentration has been determined using a solid-phase fluorescent immunoassay.

CKD has been defined as an eGFR $<60 \mathrm{~mL} / \mathrm{min} / 1.73$ $\mathrm{m}^{2}$; ALB as a urinary albumin-to-creatinine ratio (UACR) $\geq 20 \mathrm{mg} / \mathrm{g}$ for males and $\geq 30 \mathrm{mg} / \mathrm{g}$ for females; smoke by self-reported data: participants who reported having smoked $\geq 100$ cigarettes during their lifetime were classified as smokers.

Significant differences in the relative frequencies of CKD and ALB have been calculated by means of a multivariate logistic regression model including age, gender, race/ethnicity, BMI and smoking habits.

Continuous variables were tested for normality of distribution by means of numerical methods (skewness and kurtosis) and all resulted non normally distributed, so their values were reported as median (interquartile range). Categorical variables were reported as total number (percent). Linear relations between continuous variables have been evaluated by Spearman correlation. An eGFR $<10 \mathrm{~mL} / \mathrm{min}$ or $>130 \mathrm{~mL} / \mathrm{min}$ have not been considered for linear analysis. Mann-Whitney and KruskalWallis tests have been performed for comparison of continuous variables between two or more groups, respectively. When using the Kruskal-Wallis test, differences between groups have been carried out by Mann-Whitney tests for pairs of groups if the overall $\mathrm{F}$ was significant. For comparisons between categorical variables the Chisquare test has been used. The accepted level for a twotailed significant difference was $P<0.05$. All statistical analyses were performed by using the survey package in the R statistical language to account for the complex sampling design and weights in NHANES surveys. Figures have been obtained with GraphPad Prism version 5.0 (GraphPad Software, San Diego, CA, USA). 
The NHANES survey is subject to the CDC/NCHS Ethics Review Board (ERB) to ensure that appropriate human subjects protections are provided, in compliance with 45 CFR part 46.

\section{Results}

The overall analysis included 5426 subjects, whose characteristics are shown in Table 1.

Urinary Cd levels were significantly higher in smokers $(0.39(0.46) \mathrm{mcg} / \mathrm{g})$ compared with non smokers $(0.23$ $(0.25) \mathrm{mcg} / \mathrm{g})(P<0.001)$. Blood Cd levels were significantly higher in smokers $(0.60(0.52) \mathrm{mcg} / \mathrm{L})$ compared with non smokers $(0.30(0.20 \mathrm{mcg} / \mathrm{g})(P<0.001)$. Furthermore, there was a positive correlation between blood cotinine, a metabolite of nicotine, and both blood $\mathrm{Cd}(\mathrm{r}=$ $0.44, P<0.001)$ and urinary $\mathrm{Cd}(\mathrm{r}=0.12, P<0.001)$.

Urinary Cd was higher in females $(0.33(0.38) \mathrm{mcg} / \mathrm{g})$ compared with males $(0.25(0.32) \mathrm{mcg} / \mathrm{g})(P<0.001)$. Blood Cd levels were similar between females $(0.40(0.33)$ $\mathrm{mcg} / \mathrm{L})$ and males $(0.40(0.50) \mathrm{mcg} / \mathrm{L})(P=0.137)$.

Urinary and blood $\mathrm{Cd}$ were significantly related with $\operatorname{UACR}(\mathrm{r}=0.22$ for urinary Cd, $\mathrm{r}=0.09$ for blood $\mathrm{Cd})$ and eGFR $(r=-0.32$ for urinary $\mathrm{Cd}, \mathrm{r}=-0.15$ for blood $\mathrm{Cd})(P$ $<0.001$ for each correlation).

\section{Table 1: Characteristics of the study population}

\begin{tabular}{ll}
\hline Age (years) & $47(32)$ \\
\hline Males & $2644(48.7 \%)$ \\
\hline Race/ethnicity & \\
- Mexican American & $1226(22.6 \%)$ \\
- Non Hispanic White & $2740(50.5 \%)$ \\
- Non Hispanic Black & $1072(19.8 \%)$ \\
- Other & $388(7.2 \%)$ \\
\hline BMI (Kg/m $\left.{ }^{2}\right)$ & $27.5(7.4)$ \\
\hline Smokers & $2649(48.8 \%)$ \\
\hline eGFR (mL/min/1.73 m²) & $98(35)$ \\
\hline Chronic kidney disease & $447(8.2 \%)$ \\
\hline UACR (mg/g) & $6.7(9.3)$ \\
\hline Albuminuria & $0.40(0.38)$ \\
\hline Urinary Cd (mcg/g) & \\
\hline & \\
\hline
\end{tabular}

Urinary Cd was higher in subjects with CKD $(0.40$ $(0.38) \mathrm{mcg} / \mathrm{g})$ compared with subjects without CKD $(0.28$ $(0.35) \mathrm{mcg} / \mathrm{g})(P<0.001)$ and in subjects with ALB $(0.38$ $(0.44) \mathrm{mcg} / \mathrm{g})$ compared with subjects without ALB $(0.27$ $(0.34) \mathrm{mcg} / \mathrm{g})(P<0.001)$.

Blood Cd was higher in subjects with CKD $(0.50(0.40)$ $\mathrm{mcg} / \mathrm{L})$ compared with subjects without CKD $(0.40(0.40)$ $\mathrm{mcg} / \mathrm{L})(P<0.001)$ and in subjects with ALB $(0.50(0.40)$ $\mathrm{mcg} / \mathrm{L})$ compared with subjects without ALB (0.50 (0.40) $\mathrm{mcg} / \mathrm{L})(P<0.001)$.

The logistic regression analysis of the association between blood and urinary Cd and CKD and ALB adjusted for age, gender, race/ethnicity and BMI showed a significant association between blood Cd levels $>1$ $\mathrm{mcg} / \mathrm{L}$ and both CKD (OR 1.48, 95\% CI 1.01, 2.17) $(P=$ $0.046)$ and ALB (OR 1.41, 95\% CI 1.10, 1.82) $(P=0.007)$; a significant association was also found between urinary Cd levels $>1 \mathrm{mcg} / \mathrm{g}$ and ALB (OR 1.63, 95\% CI 1.23, 2.16) $(P=0.001)$ but not CKD $($ OR $0.70,95 \%$ CI $0.47,1.04)(P=$ $0.079)$.

The results of the univariate and multivariate regression models, including an analysis of the interaction effect of urinary and blood $\mathrm{Cd}$ are shown in Table 2 and Figure 1.

Finally, receiver operating characteristic (ROC) curves were performed to test the predictivity of urinary and blood Cd levels with regard to presence of CKD and ALB (Figure 2).

The areas under the ROC (AUROC) curve for CKD were 0.62 for urinary $\mathrm{Cd}(95 \% \mathrm{CI} 0.60,0.65)$ and 0.60 (95\% CI 0.57, 0.62) for blood Cd. Urinary Cd showed a sensitivity $>70 \%$ for levels $\geq 0.27 \mathrm{mcg} / \mathrm{g}$ and a specificity $>70 \%$ for levels $\geq 0.44 \mathrm{mcg} / \mathrm{g}$, while blood Cd showed a sensitivity $>70 \%$ for levels $\geq 0.39 \mathrm{mcg} / \mathrm{L}$ and a specificity $>70 \%$ for levels $\geq 0.55 \mathrm{mcg} / \mathrm{L}$.

The areas under the ROC (AUROC) curve for ALB were 0.60 for urinary $\mathrm{Cd}(95 \% \mathrm{CI} 0.58,0.62)$ and 0.57 for blood Cd (95\% CI 0.55, 0.59). Urinary Cd showed a sensitivity $>70 \%$ for levels $\geq 0.24 \mathrm{mcg} / \mathrm{g}$ and a specificity $>70 \%$ for levels $\geq 0.43 \mathrm{mcg} / \mathrm{g}$, while blood $\mathrm{Cd}$ showed a sensitivity $>70 \%$ for levels $\geq 0.31 \mathrm{mcg} / \mathrm{L}$ and a specificity $>70 \%$ for levels $\geq 0.54 \mathrm{mcg} / \mathrm{L}$.

\section{Discussion}

Navas-Acien et al [8] have recently reported in the large 1999-2006 NHANES adult population, a representative sample of the general United States adult population, the existence of an association between renal dysfunction and blood $\mathrm{Cd}$ supporting previous findings that $\mathrm{Cd}$ is a nephrotoxin even at low level exposition [13]. In this study we confirm, in the subset of the same NHANES population who has urinary $\mathrm{Cd}$ data, that blood $\mathrm{Cd}$ is associated with impaired renal function and proteinuria. 
Table 2: Results of the multivariate logistic regression

\begin{tabular}{|c|c|c|c|c|c|c|}
\hline & \multicolumn{3}{|c|}{ CKD } & \multicolumn{3}{|c|}{ ALB } \\
\hline & OR & $95 \% \mathrm{Cl}$ & Sig. $(P)$ & OR & $95 \% \mathrm{Cl}$ & Sig. $(P)$ \\
\hline \multicolumn{7}{|c|}{ Urinary Cd - univariate model } \\
\hline \multicolumn{7}{|l|}{ Urinary Cd } \\
\hline$-\leq 1 \mathrm{mcg} / \mathrm{g}$ & Ref & Ref & - & Ref & Ref & - \\
\hline$->1 \mathrm{mcg} / \mathrm{g}$ & 1.61 & $1.14,2.28$ & 0.007 & 2.23 & $1.72,2.89$ & $<0.001$ \\
\hline \multicolumn{7}{|c|}{ Urinary Cd - multivariate model } \\
\hline \multicolumn{7}{|l|}{ Urinary Cd } \\
\hline$-\leq 1 \mathrm{mcg} / \mathrm{g}$ & Ref & Ref & - & Ref & Ref & - \\
\hline$->1 \mathrm{mcg} / \mathrm{g}$ & 0.70 & $0.47,1.04$ & 0.079 & 1.63 & $1.23,2.16$ & 0.001 \\
\hline Age (1 year) & 1.12 & $1.11,1.13$ & $<0.001$ & 1.04 & $1.03,1.04$ & $<0.001$ \\
\hline \multicolumn{7}{|l|}{ Gender } \\
\hline - Female & Ref & Ref & - & Ref & Ref & - \\
\hline - Male & 1.28 & $1.01,1.62$ & 0.039 & 0.65 & $0.55,0.77$ & $<0.001$ \\
\hline BMI (1 Kg/m²) & 1.03 & $1.01,1.05$ & 0.002 & 1.04 & $1.03,1.05$ & $<0.001$ \\
\hline \multicolumn{7}{|l|}{ Race/ethnicity } \\
\hline - Mexican american & Ref & Ref & - & Ref & Ref & - \\
\hline - Non-hispanic white & 3.50 & $2.00,6.11$ & $<0.001$ & 1.16 & $0.84,1.62$ & 0.371 \\
\hline - Non Hispanic black & 2.65 & $1.82,3.86$ & $<0.001$ & 0.65 & $0.53,0.80$ & $<0.001$ \\
\hline - Other & 1.89 & $1.20,2.97$ & $<0.001$ & 1.12 & $0.89,1.42$ & 0.325 \\
\hline
\end{tabular}

Blood Cd - univariate model

\section{Blood Cd}

$-\leq 1 \mathrm{mcg} / \mathrm{L}$

$->1 \mathrm{mcg} / \mathrm{L}$
Ref

0.96
Ref

$0.70,1.32$
$-$

0.007
Ref

1.28
Ref

$1.02,1.61$

0.034

\section{Blood Cd - multivariate model}

\section{Blood Cd}

$$
-\leq 1 \mathrm{mcg} / \mathrm{L}
$$

- > $1 \mathrm{mcg} / \mathrm{L}$

$$
\text { Ref }
$$

Ref

1.48

$1.01,2.17$

-

Ref

1.41

Ref

$1.10,1.82$

0.007

Age (1 year)

1.12

$1.11,1.13$

$<0.001$

1.04

$1.03,1.04$

$<0.001$

Gender

- Female
- Male


Table 2: Results of the multivariate logistic regression (Continued)

\begin{tabular}{lcccccc}
\hline BMI $\left(1 \mathrm{Kg} / \mathrm{m}^{2}\right)$ & 1.04 & $1.02,1.06$ & $<0.001$ & 1.04 & $1.02,1.05<0.001$ \\
\hline $\begin{array}{l}\text { Race/ethnicity } \\
\text { - Mexican american }\end{array}$ & Ref & Ref & - & Ref & Ref & - \\
- Non-hispanic white & 3.29 & $1.88,5.76$ & $<0.001$ & 1.15 & $0.83,1.60$ & 0.405 \\
- Non Hispanic black & 2.66 & $1.83,3.88$ & $<0.001$ & 0.64 & $0.52,0.79$ & $<0.001$ \\
- Other & 1.88 & $1.19,2.95$ & 0.006 & 1.10 & $0.87,1.38$ & 0.456 \\
\end{tabular}

Interaction urinary/blood Cd

\begin{tabular}{|c|c|c|c|c|c|c|}
\hline \multicolumn{7}{|l|}{ Urinary/blood Cd } \\
\hline$-\leq 1 \mathrm{mcg} / \mathrm{g}-1 \mathrm{mcg} / \mathrm{L}$ & Ref & Ref & - & Ref & Ref & - \\
\hline$->1 \mathrm{mcg} / \mathrm{g}-1 \mathrm{mcg} / \mathrm{L}$ & 1.01 & $0.60,1.27$ & 0.964 & 1.62 & $1.10,2.38$ & 0.014 \\
\hline
\end{tabular}

Although blood Cd increases promptly following exposure, the blood $\mathrm{Cd}$ concentration is considered to be a less reliable marker of health effects than the urinary excretion [9], and actually most of the papers investigating renal toxicity by $\mathrm{Cd}$ have analyzed the urinary excretion of the metal [14]. It seems that the chronic accumulation of $\mathrm{Cd}$ in the renal cortex is responsible for the nephrotoxicity [15], and the cortical content is mirrored by the urinary excretion of $\mathrm{Cd}$ [16].

Present data shows the association of marginally high urinary $\mathrm{Cd}$ excretion with abnormal albuminuria, while no relationship was evidenced with CKD (eGFR $<60 \mathrm{~mL} /$ $\min / 1.73 \mathrm{~m}^{2}$ ). ROC curve analysis shows a prediction of urinary $\mathrm{Cd}$ for both CKD and albuminuria.

Urine concentrations above $10 \mathrm{mcg} / \mathrm{g}$ of creatinine are considered evidence of excessive exposure to $\mathrm{Cd}$ [17], although the U.S. Occupational Safety and Health Administration considers $3 \mathrm{mcg} / \mathrm{g}$ of creatinine as the safety standard for urinary Cd. Very few Americans are exposed to such high levels of Cd: of the investigated subjects in the 1999-2006 NHANES surveys, no one had urinary $\mathrm{Cd}$ levels above $10 \mathrm{mcg} / \mathrm{g}$ and only 8 exceeded 3 $\mathrm{mcg} / \mathrm{g}$. However, our analysis suggest that even low urinary levels of $\mathrm{Cd}$, an order of magnitude lower than those considered as toxic in industrial medicine, may have adverse effects on the kidney and a much higher number of Americans have such an urinary excretion of Cd (645 subjects [12.6\%] had urinary Cd levels $>0.75 \mathrm{mcg} / \mathrm{g}$ in our study). The suspect that a mild exposition to $\mathrm{Cd}$, as mirrored by urinary $\mathrm{Cd}$ levels in the same order of magnitude of the present one, is possibly responsible for renal dysfunction was raised in a small post-menopausal female population in Sweden [18]. Our study confirms that this may be the case, proposing $\mathrm{Cd}$ as a potential, rel- evant contributor to the epidemics of CKD observed nowadays.

An association between kidney disease and $\mathrm{Cd}$ was first noted at the end of the $19^{\text {th }}$ century, but the distinctive tubular proteinuria was not recognized until the 1940s [19]. For a long period, however, it remained unclear whether Cadmium nephropathy was the result of concomitant Lead nephropathy or of the effects of urinary tract obstruction. As a matter of fact, Cd workers are frequently exposed also to $\mathrm{Pb}$ that induces chronic tubulointerstitial nephritis, and kidney stones are common among Cd workers [20]. Nevertheless, the role of Cd as a nephrotoxin in humans is now widely acknowledged [21] and it is known that the relative mortality from kidney disease is increased among Cd workers [22]. Since in the 1999-2006 NHANES surveys no question regarded renal stones it was not possible to investigate whether nephrolithiasis played any role in the association between renal dysfunction and Cd levels.

A study on a sub-sample of the presently investigated population (NHANES 1999-2000, 2001-2002, 2003-2004) has been published which discloses the association of blood $\mathrm{Cd}$, but not urinary $\mathrm{Cd}$, with a modest elevation in blood pressure levels [7]. These data suggest that the relationship between blood Cd and CKD (as here defined, i.e. GFR $<60 \mathrm{~mL} / \mathrm{min} / 1.73 \mathrm{~m}^{2}$ ) is hemodynamic, thus highly susceptible to acute effects as those possibly depending on acute variations of blood $\mathrm{Cd}$ levels.

Besides industrial pollution, other sources of $\mathrm{Cd}$ exposure are cigarette smoke, ingestion of polluted vegetables, and ambient air in urban-industrialized areas [5,23,24]. The significant correlation we observed between blood levels of cotinine and $\mathrm{Cd}$ may suggest that cigarette smoking is responsible for such a low level exposure to $\mathrm{Cd}$. Cigarette smoke contains about 4000 chemical sub- 


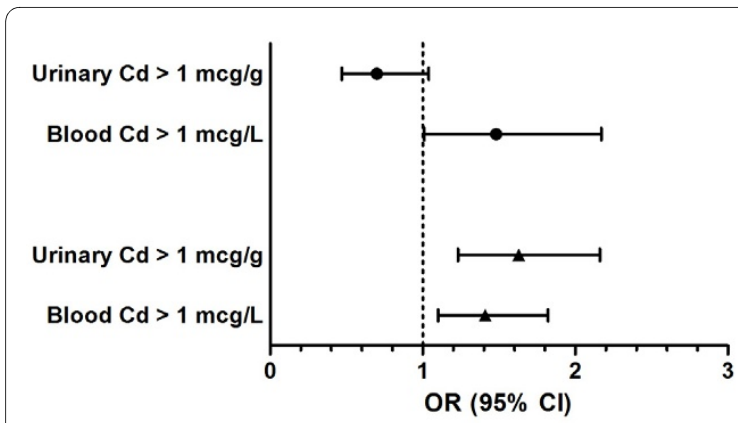

Figure 1 Odds Ratios for CKD and ALB by levels of urinary and blood Cd. Circles represent CKD, triangles represent ALB.

stances, including toxic metals such as Cd. Smoking 20 cigarettes a day results in inhalation of an average 3.6-6.0 $\mathrm{mcg}$ of $\mathrm{Cd}[25]$. It was shown that while the cigarette is burning, $30 \%$ of $\mathrm{Cd}$ and $11 \%$ of $\mathrm{Pb}$ present in the whole cigarette is released into the smoke; moreover, for $\mathrm{Cd}$, as opposite to $\mathrm{Pb}$, there is a high positive correlation between the metal content in cigarettes and tobacco and its release into the smoke; and finally, subjects smoking cigarettes containing the highest $\mathrm{Cd}$ amount have higher blood Cd concentration than smokers of low $\mathrm{Cd}$ content cigarette brands [26]. In $\mathrm{Cd}$ and $\mathrm{Pb}$ unpolluted areas, cigarette smoking may thus create a serious source of chronic exposure to these metals, especially to $\mathrm{Cd}$ [25].

The strong points of our study include the well-characterized NHANES datasets, large sample size, and U.S. nationally representative data. Since several potential confounders were collected as part of the NHANES, we were able to examine the association between $\mathrm{Cd}$ exposure and CKD and albuminuria - both well established risk factors for end stage renal disease in the general population [27] - after adjustment for potential confounders. Limitations include the fact that $\mathrm{Cd}$ urinary levels were low, close to the detection limit of the instrument.. Since the NHANES is a cross-sectional study it is not possible to infer causality between risk factors and CKD. Furthermore, the concept of chronicity of the renal dysfunction is vague since only a small subsample of the investigated NHANES population underwent a second evaluation of albuminuria. This may be relevant to the interpretation of present results. Actually we cannot confirm that the albuminuria found to be associated with urinary $\mathrm{Cd}$ levels is really chronic and irreversible. Typical markers of proximal tubular dysfunction such as $\beta 2$-microglobulin, which is considered as one of the best indicators of $\mathrm{Cd}$-induced nephropathy, could not be investigated since they were not collected during the NHANES. Since albumin is handled by the proximal tubule as a LMW protein, albuminuria per se could be a marker of a dysfunction in the proximal tubule machinery for LMW protein reabsorp-
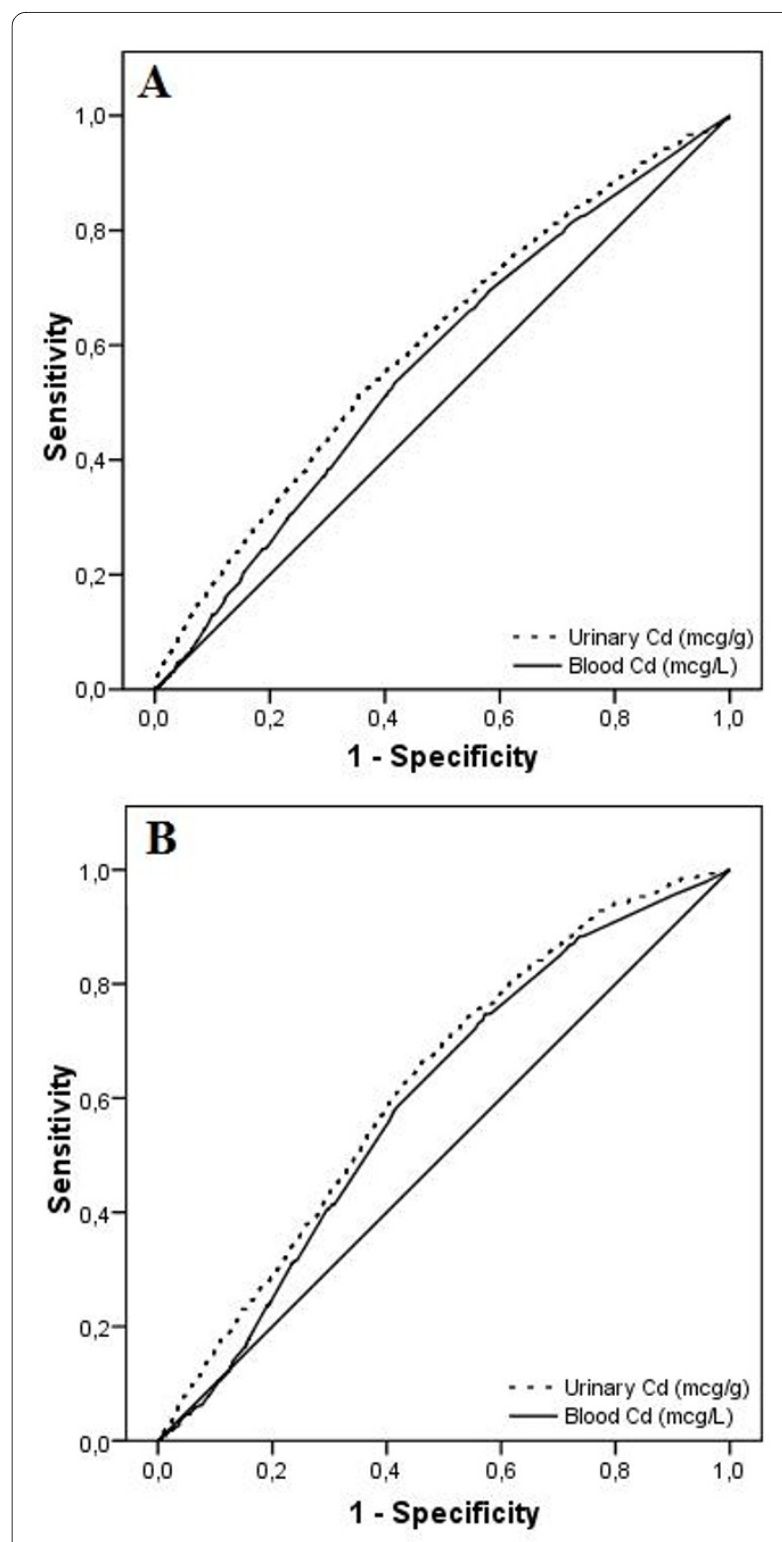

Figure 2 ROC curves for ALB and CKD by levels of urinary and blood Cd. ROC curves for ALB (A) and for CKD (B) by levels of urinary and blood $\mathrm{Cd}$

tion [28] which may not constitute a "chronic kidney disease" condition. The Cd-metallothionein-1 complexes filtered through the glomerulus accumulate in the proximal tubule [4] where they interfere with the tubular function, and namely with the above machinery. In the typical Cadmium nephropathy, proximal tubular dysfunction persists until renal failure supervenes but this is considered to occur following much more relevant exposure to $\mathrm{Cd}$. It is not known if low level exposure to $\mathrm{Cd}$ induces an irreversible dysfunction in tubular biology, more severe than the simple interference with LMW protein reab- 
sorption, or reverts after giving up exposition to $\mathrm{Cd}$. This interpretation requires experimental verification at these low levels of exposure to $\mathrm{Cd}$.

In conclusion, data from the large general population of the NHANES suggest that the chronic exposition to low level $\mathrm{Cd}$ is associated with albuminuria, a well known marker of renal dysfunction and may concur in explaining the epidemics of chronic kidney disease.

\section{Conclusions}

In a large sample of the general population, levels of urinary and blood Cd below the accepted thresholds are associated with a higher proportion of kidney disease and albuminuria.

\section{Competing interests}

The authors declare that they have no competing interests.

\section{Authors' contributions \\ PMF participated in the design of the study, carried out the statistical analysis and participated in drafting the manuscript; SC participated in the design of the study; AN participated in drafting the manuscript; GG conceived the study, participated in its design and drafting and coordinated the research. All authors read and approved the final manuscript.}

\section{Acknowledgements}

National Health and Nutrition Examination Survey (NHANES) is a program of studies of the Centers for Disease Control and Prevention (CDC); National Center for Health Statistics (NCHS); National Health and Nutrition Examination Survey Data. Hyattsville, MD: U.S. Department of Health and Human Services, Centers for Disease Control and Prevention. We recognize the inestimable value for science and medical progress of the free accessibility of NHANES data by the CDC.

The authors wish to thank doctors Stefano Passalacqua, Pierluigi Fulignati, Fabio Aureli, Monica Bonello, Silvia D'Alonzo and Mariagrazia Porri (Division of Nephrology and Dialysis, Columbus-Gemelli University Hospital, Renal Program, Catholic University, Rome) for participation in collection of data and suggestions that improved the manuscript.

Part of our data have been presented to the World Congress of Nephrology 2009, Milan, Italy, as a poster.

\section{Author Details}

Division of Nephrology and Dialysis, Columbus-Gemelli University Hospital, Renal Program, Catholic University, Rome, Italy

Received: 2 December 2009 Accepted: 3 June 2010

Published: 3 June 2010

\section{References}

1. Järup L, Hellström L, Alfvén T, Carlsson MD, Grubb A, Persson B, Pettersson C, Spång G, Schütz A, Elinder CG: Low level exposure to cadmium and early kidney damage: the OSCAR study. Occup Environ Med 2000, 57:668-72.

2. Thijssen S, Maringwa J, Faes C, Lambrichts I, Van Kerkhove E: Chronic exposure of mice to environmentally relevant, low doses of cadmium leads to early renal damage, not predicted by blood or urine cadmium levels. Toxicology 2007, 229:145-56.

3. Coyle P, Philcox JC, Carey LC, Rofe AM: Metallothionein: the multipurpose protein. Cell Mol Life Sci 2002, 59:627-47

4. Erfurt C, Roussa E, Thévenod F: Apoptosis by $\mathrm{Cd}^{2+}$ or $\mathrm{CdMT}$ in proximal tubule cells: different uptake routes and permissive role of endo/ lysosomal CdMT uptake. Am J Physiol Cell Physiol 2003, 285:1367-76.

5. Gallagher CM, Kovach JS, Meliker JR: Urinary cadmium and osteoporosis in U.S. Women > or $=50$ years of age: NHANES 1988-1994 and 19992004. Environ Health Perspect 2008, 116:1338-43.
6. Mannino DM, Holguin F, Greves HM, Savage-Brown A, Stock AL, Jones RL: Urinary cadmium levels predict lower lung function in current and former smokers: data from the Third National Health and Nutrition Examination Survey. Thorax 2004, 59:194-8.

7. Tellez-Plaza M, Navas-Acien A, Crainiceanu CM, Guallar E: Cadmium exposure and hypertension in the 1999-2004 National Health and Nutrition Examination Survey (NHANES). Environ Health Perspect 2008, 116:51-6

8. Navas-Acien A, Tellez-Plaza M, Guallar E, Muntner P, Silbergeld E, Jaar B, Weaver V: Blood Cadmium and Lead and Chronic Kidney Disease in US Adults: A Joint Analysis. Am J Epidemiol 2009, 170:1156-64.

9. Nordberg GF, Nogawa K, Nordberg M, Friedmann JM: Cadmium. In Handbook on the Toxicology of Metals Edited by: Nordberg GF, Fowler BA, Nordberg M, Friberg L. Amsterdam: Elsevier; 2007:445-486.

10. CDC [Centers for Disease Control and Prevention], National Center for Health Statistics [NCHS]: National Health and Nutrition Examination Survey Data. 1999 [http://www.cdc.gov/nchs/nhanes.htm]. Hyattsville, MD: U.S. Department of Health and Human Services, Centers for Disease Control and Prevention

11. Levey AS, Stevens LA, Schmid CH, Zhang YL, Castro AF, Feldman HI, Kusek JW, Eggers P, Van Lente F, Greene T, Coresh J, CKD-EPI (Chronic Kidney Disease Epidemiology Collaboration): A new equation to estimate glomerular filtration rate. Ann Intern Med 2009, 150:604-12.

12. Coresh J, Astor B, McQuillan G, Kusek J, Greene T, Van Lente F, Levey AS: Calibration and random variation of the serum creatinine assay as critical elements of using equations to estimate the glomerular filtration rate. Am J Kidney Dis 2002, 39:920-29.

13. Nordberg GF, Jin T, Wu X, Lu J, Chen L, Lei L, Hong F, Nordberg M: Prevalence of kidney dysfunction in humans - relationship to cadmium dose, metallothionein, immunological and metabolic factors. Biochimie 2009, 91:1282-5.

14. Bernard A: Cadmium \& its adverse effects on human health. Indian J Med Res 2008, 128:557-64.

15. Barbier O, Jacquillet G, Tauc M, Cougnon M, Poujeol P: Effect of heavy metals on, and handling by, the kidney. Nephron Physio/ 2005 99:105-10.

16. Friberg L: Cadmium and the kidney. Environ Health Perspect 1984 54:1-11

17. Wedeen RP, De Broe ME: Nephrotoxic metals. In Oxford Textbook of Clinical Nephrology 3rd edition. Edited by: Davison AM, Cameron JS, Grunfeld J-P, Ponticelli C, Ritz E, Winearls CG, van Ypersele C. Oxford University Press: Oxford; 2004:1077-1089.

18. Akesson A, Lundh T, Vahter M, Bjellerup P, Lidfeldt J, Nerbrand C, Samsioe $\mathrm{G}$, Strömberg U, Skerfving S: Tubular and glomerular kidney effects in Swedish women with low environmental cadmium exposure. Environ Health Perspect 2005, 113:1627-31.

19. Friberg L: Proteinuria and kidney injury among workmen exposed to cadmium and nickel dust; preliminary report. J Ind Hyg Toxicol 1948, 30:32-6.

20. Järup L, Elinder CG: Incidence of renal stones among cadmium exposed battery workers. Br J Ind Med 1993, 50:598-602.

21. Cadmium. Environmental health criteria Geneva: World Health Organization; 1992

22. Andersson K, Elinder CG, Hogstedt C, Nuyts GD, Van Viem E: Mortality among cadmium and nickel-exposed workers in a Swedish battery factory. Toxicol Environ Chem 1984, 9:53-62.

23. Järup L, Berglund M, Elinder CG, Nordberg G, Vahter M: Health effects of cadmium exposure--a review of the literature and a risk estimate. Scand J Work Environ Health 1998, 1:1-51. Erratum in: Scand J Work Environ Health 1998 24: 240

24. Thomas LD, Hodgson S, Nieuwenhuijsen M, Jarup L: Early kidney damage in a population exposed to cadmium and other heavy metals. Environ Health Perspect 2009, 117:181-4.

25. Galazyn-Sidorczuk M, Brzóska MM, Moniuszko-Jakoniuk J: Estimation of Polish cigarettes contamination with cadmium and lead, and exposure to these metals via smoking. Environ Monit Assess 2008, 137:481-93.

26. Ezaki T, Tsukahara T, Moriguchi J, Furuki K, Fukui Y, Ukai H, Okamoto S, Sakurai $\mathrm{H}$, Honda S, Ikeda M: No clear-cut evidence for cadmiuminduced renal tubular dysfunction among over 10,000 women in the Japanese general population: a nationwide large-scale survey. Int Arch Occup Environ Health 2003, 76:186-96. 
27. Hallan SI, Ritz E, Lydersen S, Romundstad S, Kvenild K, Orth SR: Combining GFR and Albuminuria to Classify CKD Improves Prediction of ESRD. $J$ Am Soc Nephrol 2009, 20:1069-77.

28. Baines RJ, Brunskill NJ: The molecular interactions between filtered proteins and proximal tubular cells in proteinuria. Nephron Exp Nephrol 2008, 110:67-71.

\section{Pre-publication history}

The pre-publication history for this paper can be accessed here:

http://www.biomedcentral.com/1471-2458/10/304/prepub

\section{doi: 10.1186/1471-2458-10-304}

Cite this article as: Ferraro et al., Low level exposure to cadmium increases the risk of chronic kidney disease: analysis of the NHANES 1999-2006 BMC Public Health 2010, 10:304

Submit your next manuscript to BioMed Central and take full advantage of:

- Convenient online submission

- Thorough peer review

- No space constraints or color figure charges

- Immediate publication on acceptance

- Inclusion in PubMed, CAS, Scopus and Google Scholar

- Research which is freely available for redistribution

Submit your manuscript at www.biomedcentral.com/submit 